\title{
Single-Channel Properties of Recombinant AMPA Receptors Depend on RNA Editing, Splice Variation, and Subunit Composition
}

\author{
Geoffrey T. Swanson, ${ }^{1,2, a}$ Sunjeev K. Kamboj, ${ }^{1, a}$ and Stuart G. Cull-Candy ${ }^{1}$ \\ ${ }^{1}$ Department of Pharmacology, University College London, London WC1E 6BT, United Kingdom, and ${ }^{2 M o l e c u l a r}$ \\ Neurobiology Laboratory, The Salk Institute, La Jolla, California 92037
}

\begin{abstract}
Non-NMDA glutamate receptor subunits of the AMPApreferring subfamily combine to form ion channels with heterogeneous functional properties. We have investigated the effects of RNA editing at the $Q / R$ site, splice variation of the "flip/flop" cassette, and multimeric subunit assembly on the single-channel conductance and kinetic properties of the recombinant AMPA receptors formed from GluR2 and GluR4 expressed in HEK 293 cells. We found that AMPA receptor single-channel conductance was dependent on the $Q / R$ site editing state of the subunits comprising the channel. Calciumpermeable (unedited) channels had resolvable single-channel events with main conductance states of 7-8 pS, whereas fully
\end{abstract}

edited GluR2 channels had very low conductances of $\sim 300 \mathrm{fS}$ (estimated from noise analysis). Additionally, the flip splice variant of GluR4 conferred agonist-dependent conductance properties reminiscent of those found for a subset of AMPA receptors in cultured cerebellar granule cells. These results provide a description of the single-channel properties of certain recombinant AMPA receptors and suggest that the singlechannel conductance may be determined by the expression of edited GluR2 subunits in neurons.

Key words: glutamate receptor; AMPA receptor; singlechannel conductance; RNA editing; alternative splicing; patchclamp electrophysiology
Non-NMDA receptors mediate fast excitatory synaptic transmission at glutamate synapses in the mammalian CNS. Cloning techniques have led to the identification of nine non-NMDA receptor genes (Hollmann and Heinemann, 1994), which have been separated into AMPA-preferring (GluR1-4 or GluRA-D) and kainate-preferring (GluR5-7, KA-1, and KA-2) subfamilies on the basis of structural and functional similarities. AMPA receptor subunits have two splice variants ("flip" and "flop," denoted by "i" and "o"), which differ by seven residues in a 38 amino acid cassette between the third and fourth putative transmembrane domains (Sommer et al., 1990). Furthermore, gene splicing can give rise to alternative C-terminal sequences (Gallo et al., 1992; Köhler et al., 1994). These isoforms can differ in their pharmacological properties as well as their desensitization kinetics (Mosbacher et al., 1994; Partin et al., 1995). Whether the flip/flop variation affects single-channel properties is unknown.

RNA editing creates further diversity among non-NMDA receptor subunits, which show single positions occupied by one of two amino acids. For AMPA subunits, these are the "Q/R" and "R/G" sites (Sommer et al., 1991; Lomeli et al., 1994; for review, see Seeburg, 1996). Single nucleotide editing of AMPA and

Received July 8, 1996; revised Oct. 4, 1996; accepted Oct. 8, 1996.

This work was supported by the Wellcome Trust. G.T.S. was supported by a Hitchings-Elion Fellowship from the Wellcome Trust and the Burroughs Wellcome Fund. S.K.K. was in receipt of a Wellcome Studentship. The work of S.G.C.-C. is supported in part by an International Scholars Award from The Howard Hughes Medical Institute. GluR2(i) and GluR4(i) plasmid cDNAs were kindly provided by Peter Seeburg. GluR2(o) plasmid DNA was kindly provided by Stephen Heinemann and Jim Boulter. GluR2Q(o) was generated by Andreas Sailer. We thank David Colquhoun for generous help with software for single-channel analysis and John Dempster for SPECTAN analysis software. We thank Mark Farrant, Zoltan Nusser, Alasdair Gibb, David Wyllie, and Mark Mayer for helpful discussions and comments on this manuscript, and Stephen Heinemann for additional support for G.T.S.

Correspondence should be addressed to Stuart G. Cull-Candy, Department of

Pharmacology, University College London, Gower Street, London WC1E 6BT, UK.

${ }^{a}$ These authors contributed equally to this work.

Copyright (C) 1996 Society for Neuroscience $0270-6474 / 96 / 170058-12 \$ 05.00 / 0$ kainate receptor subunits at the codon for the $Q / R$ site of the receptor involves the replacement of a glutamine by an arginine in the pore-lining region (M2) of GluR2, -5, and -6 (Sommer et al., 1991). This results in a reduction of the calcium permeability (Hume et al., 1991; Burnashev et al., 1992) accompanied by a loss of sensitivity to intracellular polyamines, which confer inward rectification on these receptors (Bowie and Mayer, 1995; Kamboj et al., 1995; Koh et al., 1995). Furthermore, Q/R site editing reduces the single-channel conductance of kainate receptors by as much as 25-fold (Swanson et al., 1996). The finding that GluR2 mRNA is completely edited at birth (Sommer et al., 1991) and that the expression level of GluR2 subunits controls the calcium permeability of AMPA receptors within certain cell types (Geiger et al., 1995; Jonas and Burnashev, 1995) has provided a further stimulus to understanding the effect of $Q / R$ site editing on the single-channel properties of AMPA receptors.

To investigate this further and to obtain clues about the subunit composition of native AMPA receptor channels, we have examined the single-channel properties of combinations of GluR2 and GluR4 subunits. These receptors were of interest, because nonNMDA channels in cerebellar granule cells, which have been described in detail (Cull-Candy et al., 1988; Wyllie et al., 1993), probably arise from these subunits (Monyer et al., 1991; Mosbacher et al., 1994). We have found that the single-channel conductance is relatively high for calcium-permeable AMPA receptors but lower for calcium-impermeable channels containing edited subunits. Furthermore, heteromeric channels formed by coexpression of the unedited form of GluR2 [GluR2Q(o)], together with GluR4(i), had a markedly higher conductance than GluR2R(o)/GluR4(i) channels. These results strongly suggest that one consequence of $\mathrm{Q} / \mathrm{R}$ site editing is a reduction in the conductance of AMPA receptors. Finally, our results have identified at least two recombinant channels whose single-channel properties correspond closely to those of native non-NMDA 
Table 1. Conductance properties of recombinant AMPA receptors formed from GluR2 and GluR4

\begin{tabular}{|c|c|c|c|c|c|}
\hline \multicolumn{3}{|l|}{ Unedited } & \multicolumn{3}{|l|}{ Edited } \\
\hline Receptor & Conductance (pS) & Agonist & Receptor & Conductance (pS) & Agonist \\
\hline \multirow[t]{3}{*}{ GluR4Q(i) } & $7 / 16 / 27$ & AMPA & GluR2R(i) & $0.21^{*}$ & AMPA \\
\hline & $8 / 15 / 24$ & Glutamate & & $0.36^{*}$ & Glutamate \\
\hline & $2.5^{*}$ & Kainate & & $0.45^{*}$ & Kainate \\
\hline GluR4Q(o) & $4.0^{*}$ & Kainate & GluR2R(o) & $<0.3^{*}$ & Kainate \\
\hline GluR2Q(o)/4Q(i) & $7 / 15 / 24$ & AMPA & GluR2R(o)/4Q(i) & $4 / 9$ & AMPA \\
\hline \multirow{2}{*}{-} & & & & $\sim 4 / 10$ & Glutamate \\
\hline & & & & $0.50^{*}$ & Kainate \\
\hline- & - & - & GluR2R(i)/4Q(o) & $1.0^{*}$ & Glutamate \\
\hline
\end{tabular}

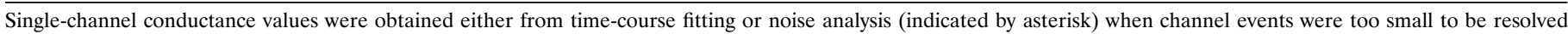
directly.

channels found in cerebellar granule cells (Cull-Candy et al., 1988; Wyllie et al., 1993). This suggests that analysis of single-channel properties of recombinant AMPA receptors can be useful in determining the subunits constituting native receptors and extends earlier work examining macroscopic properties of recombinant channels (Seeburg, 1993; Hollmann and Heinemann, 1994; Lomeli et al., 1994; Mosbacher et al., 1994).

\section{MATERIALS AND METHODS}

Maintenance and transfection of HEK 293 cells. HEK 293 cells were cultured in DMEM/F12 (Life Technologies, Gaithersburg, MD) with $10 \%$ heat-inactivated fetal bovine serum, $50 \mu \mathrm{g} / \mathrm{ml}$ penicillin, and 50 $\mu \mathrm{g} / \mathrm{ml}$ streptomycin. One day before transfection, cells were replated on $11 \mathrm{~mm}$ glass coverslips coated with $100 \mu \mathrm{g} / \mathrm{ml}$ poly-L-lysine and $50 \mu \mathrm{g} / \mathrm{ml}$ fibronectin (Sigma, Dorset, UK). Transfections were carried out using a standard $\mathrm{CaPO}_{4}$ protocol (Chen and Okayama, 1987) with $0.5 \mu \mathrm{g}$ plasmid DNA/well for 3-6 hr at $37^{\circ} \mathrm{C}$. Transfected cells were allowed to grow for 1-3 d before use. All cDNAs were harbored in a CMV promotercontaining vector. In addition to AMPA receptor subunits, some cells were cotransfected with cDNA for the cell-surface marker protein CD8. Before patch-clamp recordings, cells were exposed to polystyrene beads coated with an antibody to CD8 (Dynal, Great Neck, NY), allowing visual detection of transfected cells.

Electrophysiology. Patch-clamp recordings were made with an Axopatch 200A amplifier (Axon Instruments, Foster City, CA). Patch pipettes were pulled from thick-walled glass (Clark Electromedical GC150F-7.5, Pangbourne, UK), coated with Sylgard 184 resin (Dow Corning, Midlands, $\mathrm{MI}$ ), and fire-polished to a final resistance of $10-15 \mathrm{M} \Omega$ for outside-out patch recordings and 7-8 $\mathrm{M} \Omega$ for whole-cell recordings. The pipette solution contained (in mM): $110 \mathrm{CsF}, 30 \mathrm{CsCl}, 4 \mathrm{NaCl}, 0.5 \mathrm{CaCl}_{2}, 10$ HEPES, 5 EGTA, adjusted to $\mathrm{pH} 7.3$ with $\mathrm{CsOH}$. The external bathing solution contained (in $\mathrm{mM}$ ): $150 \mathrm{NaCl}, 2.8 \mathrm{KCl}, 1.0 \mathrm{CaCl}_{2}, 1.0 \mathrm{MgCl}_{2}, 10$ Na-HEPES (pH was adjusted to 7.3 with $\mathrm{NaOH}$ ). Currents were recorded on digital audio tape (DTR-1204; BioLogic, Claix, France). Drugs were applied by local perfusion of the recording chamber. Kainate, AMPA, and glutamate were purchased from Tocris Cookson (Bristol, UK). Cyclothiazide (CZD) was a gift from Eli Lilly.

Data analysis. Single-channel records were filtered at $2 \mathrm{kHz}(-3 \mathrm{~dB}$, 8-pole Bessel) and digitized at $20 \mathrm{kHz}$ (1401-plus interface, CED Ltd., Cambridge, UK), and individual currents were fitted by the step-response function of the recording system using the time-course fitting procedure (SCAN; Colquhoun and Sigworth, 1995). Mean unitary current amplitudes were determined from maximum likelihood fits of Gaussian distributions. Only openings longer than 1.5 or 2 filter rise-times $\left(T_{\mathrm{r}}\right)$ were included in the amplitude distributions to minimize the inclusion of false events. Open-time distributions of individual amplitudes were determined from the time-course fitting of channel openings. The resolution of openings was set to $150-200 \mu \mathrm{sec}$ for GluR4(i) and GluR2Q(o)/4(i) records and 300-500 $\mu \mathrm{sec}$ for GluR2(i)/4(i) and GluR2(o)/4(i) records. All sublevel amplitudes were included in kinetic analyses. Shut-time distributions were generated from the time-course fitted data to calculate a critical gap length, $t_{\text {crit }}$. Bursts of openings were defined as activations separated by shut-times shorter than $t_{\text {crit }}$ (typically $1-3 \mathrm{msec}$ ), which was calculated from components of the shut-time distribution. The $t_{\text {crit }}$ values included an equal number of gaps misclassified as within bursts and gaps misclassified as between bursts (Colquhoun and Sigworth, 1995). Higherorder activation clusters were not analyzed.

For spectral analysis of steady-state current responses, current records were high-pass-filtered at $0.2 \mathrm{~Hz}$, low-pass-filtered at $2 \mathrm{kHz}(-3 \mathrm{~dB}$, 8-pole Butterworth), and digitized at $4 \mathrm{kHz}$ (CED 1401 plus interface). Noise analysis was generally restricted to patches that gave a current response of $>0.5 \mathrm{pA}$. Digitized records were split into sections $1 / f_{\text {res }}$ in length (with $f_{\text {res }}$ being 1 or $2 \mathrm{~Hz}$ ) and edited to remove artifacts. Noise spectra were fitted with the sum of two Lorentzian components according to the relation $G(f)=G_{1}(0) /\left\{1+\left(f / f_{\mathrm{c} 1}\right)^{2}\right\}+G_{2}(0) /\left\{1+\left(f / f_{\mathrm{c} 2}\right)^{2}\right\}$, where $G_{1}(0)$ and $G_{2}(0)$ are the spectral densities at the zero frequency asymptote for the two Lorentzian components, $f$ is the frequency, and $f_{\mathrm{c} 1}$ and $f_{\mathrm{c} 2}$ are the corner frequencies for the fast and slow components, respectively. The contribution to the variance of each component was described by variance $=G(0) f_{\mathrm{c}} \pi / 2$.

\section{RESULTS}

We have examined homomeric and heteromeric AMPA receptors expressed in HEK 293 cells transfected with flip (i) and flop (o) isoforms of GluR2 and GluR4 subunits. Receptors that gave discrete channel openings in outside-out patches [GluR4(i), GluR2(i)/4(i), GluR2(o)/4(i), and GluR2Q(o)/4(i)] were examined in detail using time-course fitting (Colquhoun and Sigworth, 1995), whereas those receptors that were poorly responsive or had a very small conductance [GluR2(i), GluR2(o), GluR4(o), and GluR2(i)/4(o)] were examined using noise analysis. The conductance estimates obtained for these receptors are summarized in Table 1.

\section{Homomeric receptors}

GluR4(i) receptors exhibit agonist dependence of single-channel conductance

To examine the single-channel properties of a calcium-permeable AMPA receptor, we expressed GluR4(i) subunits in HEK 293 cells and applied agonists to isolated patches. Figure $1 A$ compares the current noise evoked by $300 \mu \mathrm{M}$ kainate, $100 \mu \mathrm{M}$ glutamate, and $5 \mu \mathrm{M}$ AMPA in outside-out patches from GluR4(i)transfected cells. For macroscopic currents of similar amplitude, AMPA (5-20 $\mu \mathrm{M})$ consistently produced a larger noise increase than kainate $(100-300 \mu \mathrm{M})$ or glutamate $(50-300 \mu \mathrm{M})$, suggesting a difference in the underlying channel conductance. Furthermore, single-channel events could be resolved readily in the presence of glutamate and AMPA, but were rare or difficult to detect during 


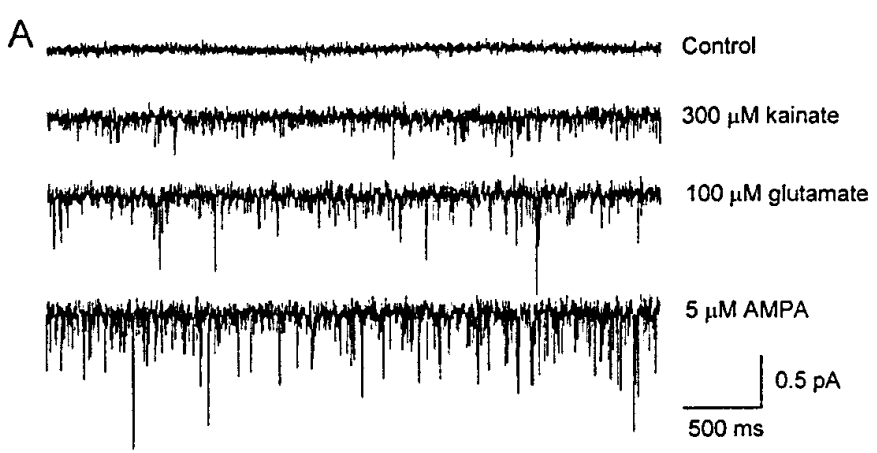

B

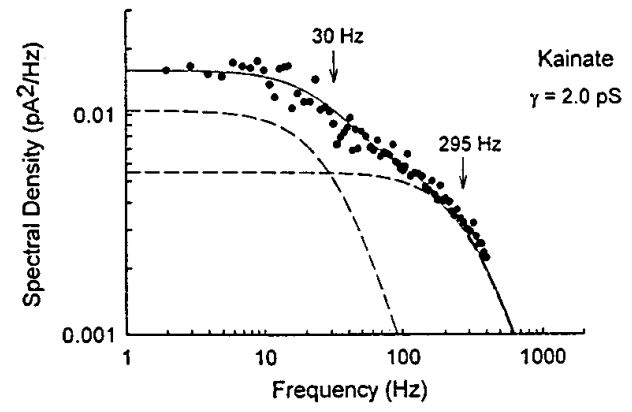

C

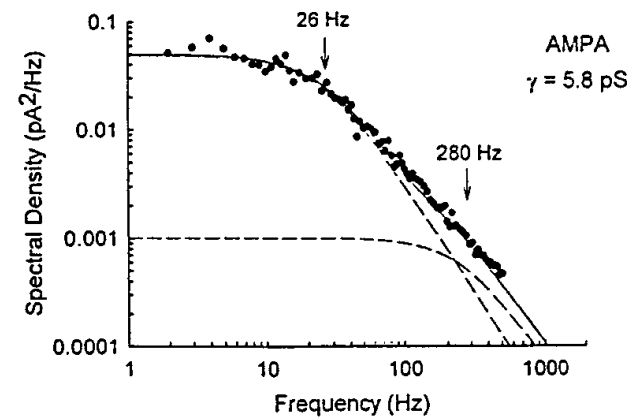

Figure 1. Agonist-dependent conductances of the homomeric GluR4(i) receptor. $A$, Current noise in control solution and in the presence of kainate, glutamate, and AMPA from outside-out patches of HEK 293 cells expressing GluR4(i). Mean inward currents activated by the three agonists are similar in amplitude and illustrate the difference in noise variance. The calibration is the same for all the responses $(0.5 \mathrm{pA}, 500 \mathrm{msec}) . B$, Noise spectrum for currents activated by $100 \mu \mathrm{M}$ kainate. The spectrum was fit to two Lorentzian components (dashed lines), as detailed in Materials and Methods. The conductance $(\gamma)$ obtained from this spectrum was $2.0 \mathrm{pS}$. The corner frequencies were 30 and $395 \mathrm{~Hz}$. C, Noise spectrum for currents activated by $10 \mu \mathrm{M}$ AMPA. The $\gamma$ obtained from this spectrum was $5.8 \mathrm{pS}$, and corner frequencies were 26 and $280 \mathrm{~Hz}$. The holding potential was $-80 \mathrm{mV}$.

the kainate noise increase. Coapplication of CZD with the agonists suppressed desensitization (Partin et al., 1995) and potentiated the current, in some cases revealing responses that were otherwise undetectable.

Because the kainate-activated channel events could not be directly resolved in patches, we used spectral analysis of kainateevoked current noise to examine the channel conductance (Fig. $1 B, C)$. This gave a single-channel conductance estimate of $\gamma($ kainate $)=2.5 \pm 0.8 \mathrm{pS}(n=5)$. There was no detectable difference in either the conductance or the cut-off frequencies when kainate was applied with CZD, so we have pooled the data from these responses. In comparison, spectral analysis of AMPA current noise gave a conductance estimate of $\gamma($ AMPA $)=5.5 \pm 0.5 \mathrm{pS}$ $(n=6)$. These conductances were significantly different (unpaired $t$ test, $p<0.05$ ). Kainate spectra were well fitted with the sum of two Lorentzian components, with time constants for the fast and slow components of $\tau_{\text {slow }}=13.5 \pm 4.0$ and $\tau_{\text {fast }}=0.25 \pm 0.05$ msec [obtained from the cut-off frequencies $f_{\mathrm{c}}$ according to $\tau=$ $\left.1 /\left(2 \pi f_{\mathrm{c}}\right)\right]$; for AMPA these were $\tau_{\text {slow }}=11.5 \pm 5.7$ and $\tau_{\text {fast }}=$ $0.52 \pm 0.17 \mathrm{msec}$. The $\tau$ values were not significantly different for the two agonists; however, the proportion of the noise variance carried by the fast component in the spectra was significantly larger for kainate $(92.7 \pm 6.9 \%)$ than for AMPA $(67.2 \pm 2.3 \%)$. Currents evoked by glutamate gave an estimated conductance of $3.2 \mathrm{pS}$ (in two patches). Furthermore, estimates of spectral parameters were not appreciably altered by reduced filtering of the noise (increasing the low-pass filtering to $5 \mathrm{kHz}$; data not shown). Whole-cell recordings gave similar conductance values for these agonists, indicating that patch excision did not markedly alter the mean single-channel conductance. Thus, the estimated channel conductance of homomeric GluR4(i) receptors seemed to depend on the agonist used. It has been shown previously that although the kinetic properties of ligand-gated ion channels are agonistdependent, the single-channel conductance is usually independent of the agonist (Barker and Mathers, 1981; Cull-Candy et al., 1981; Gardner et al., 1984). To investigate this phenomenon further, we examined directly resolved single-channel currents of GluR4(i) homomeric receptors in isolated patches.

Figure $2 A$ shows responses to the three agonists on a fast time base. Kainate typically activated a noise increase in patches, with occasional brief channel events superimposed on the channel noise. These events were too infrequent to permit detailed singlechannel analysis. In contrast, AMPA and glutamate activated brief, discrete channel openings to multiple conductance levels (Fig. 2A). Previous studies on native AMPA receptors have also reported an apparently higher conductance when AMPA rather than kainate is used as the agonist (Jonas and Sakmann, 1992; Wyllie et al., 1993). Time-course fitting of the openings produced by AMPA and glutamate gave amplitude distributions that were best-fitted with three Gaussian components (for both glutamate and AMPA), as shown in Figure 2, $B$ and $C$. The mean amplitudes of the multiple conductance levels activated by AMPA (and their relative proportions) were $6.5 \pm 0.2(83.6 \%), 15.7 \pm 0.5(12.5 \%)$, and $26.7 \pm 1.1 \mathrm{pS}(3.9 \%)(n=8)$. For glutamate, the corresponding levels were $7.6 \pm 0.4(74.0 \%), 15.1 \pm 0.6(17.9 \%)$, and $23.5 \pm$ $0.7 \mathrm{pS}(8.1 \%)(n=6)$. The presence of transitions between conductance levels, and openings to the larger levels directly from the baseline (without apparent inflection), suggested that the different levels arose from a single type of receptor channel with multiple conductance states. Unlike the response to kainate, neither AMPA $(5-20 \mu \mathrm{M})$ nor glutamate $(50-300 \mu \mathrm{M})$ produced a detectable change in the background noise (between resolved channel activations); however, brief openings that were below the resolution level imposed on the amplitude distributions (332 $\mu \mathrm{sec}$ ) were apparent with both AMPA and glutamate and may account for the difference in single-channel conductance estimates obtained from noise analysis versus time-course fitting of individual openings.

\section{Kinetic properties of the GluR4(i) receptor}

A kinetic description of the GluR4(i) channel was obtained by constructing open-time, shut-time, and burst-length distributions for AMPA- and glutamate-activated channel currents. Figure $3 A$ shows a typical open-time distribution for AMPA-activated events. These were generally fitted well to a single exponential 
A control

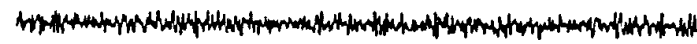

$100 \mu \mathrm{M}$ kainate

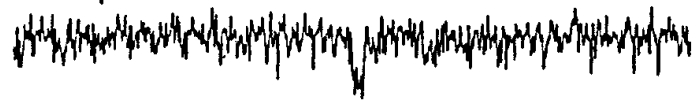

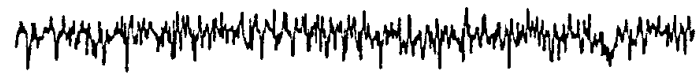

$10 \mu \mathrm{M}$ AMPA

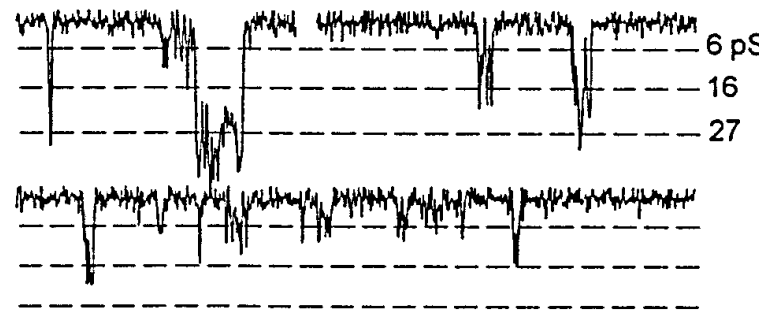

$100 \mu \mathrm{M}$ glutamate
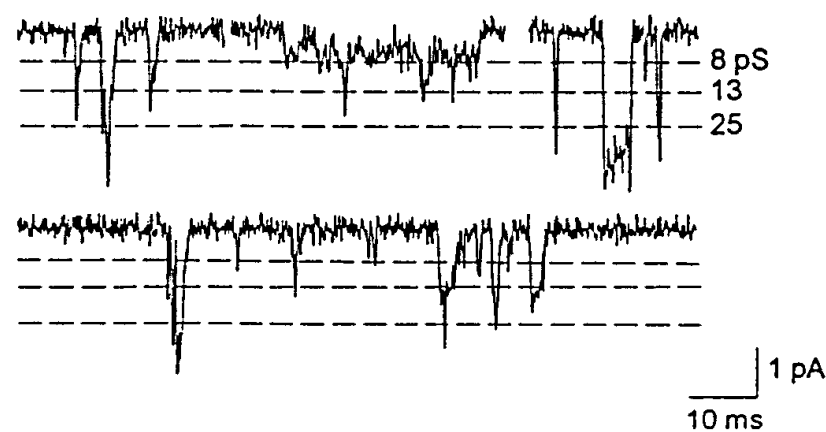

B

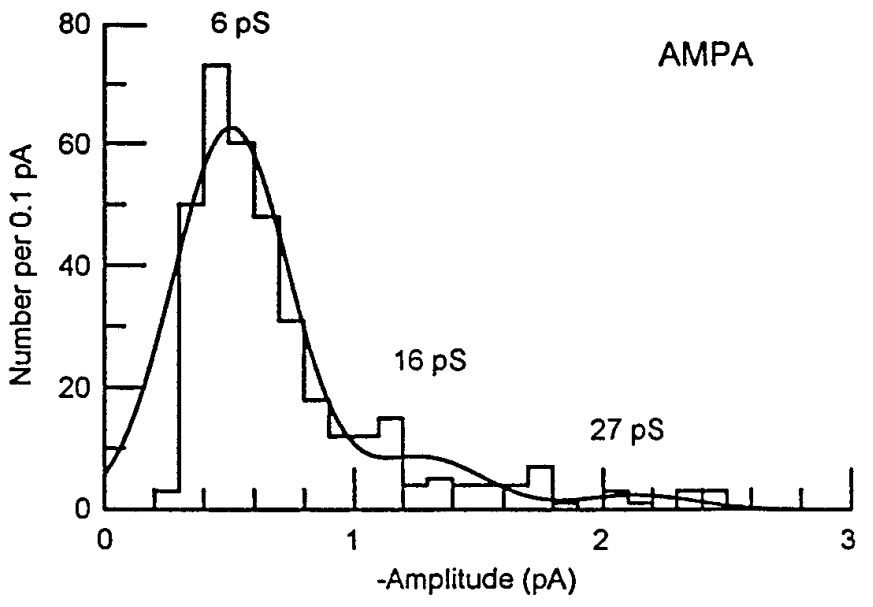

C

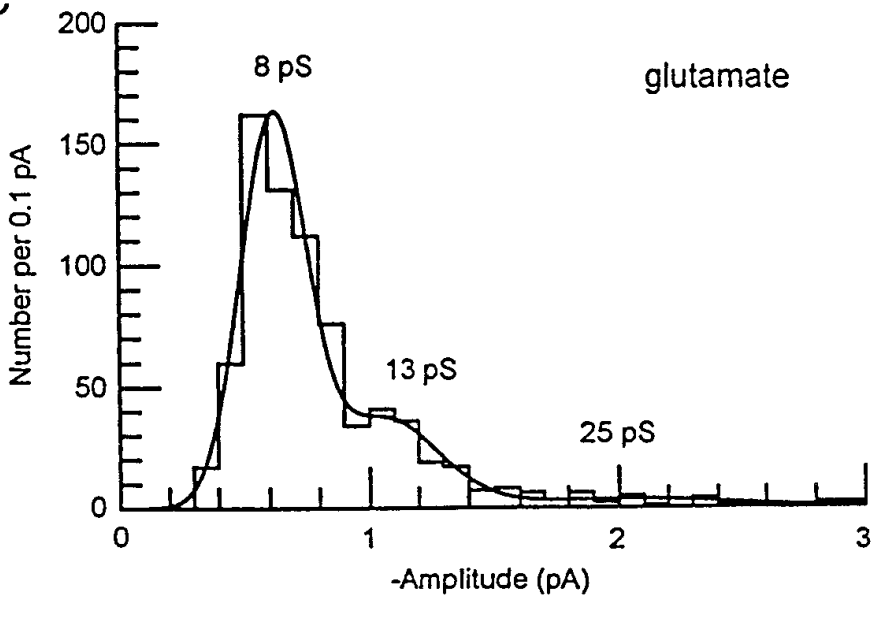

Figure 2. GluR4(i) single channels and amplitude histograms. A, Baseline noise and single-channel responses elicited by kainate, AMPA, and glutamate in GluR4(i)-containing patches. A channel-like event superimposed on the kainate-induced noise can be seen in the second trace. The dashed lines indicate the approximate size of the conductance levels activated by AMPA and glutamate as determined from time-course fitting (see $B, C$ ). The holding potential was $-80 \mathrm{mV}$ in each case. $B$, Amplitude histogram generated by time-course fitting of AMPA-activated events. The distribution was fitted to three Gaussian components, which gave mean conductance levels of 6, 16, and $27 \mathrm{pS}$. $C$, Amplitude histogram generated by time-course fitting of glutamate-activated events. The distribution was fitted to three Gaussian components, which gave mean conductances of 8,15 , and $24 \mathrm{pS}$.

with a time constant of $0.20 \pm 0.01 \mathrm{msec}(n=7)$. In two patches, two exponential components were required to obtain an adequate fit of the distribution; mean time constants (and relative proportions) were $0.21(95.5 \%)$ and $0.80 \mathrm{msec}(4.5 \%)$. Shut-time distributions were fitted with four or five exponential components, depending on whether the fastest $(<100 \mu \mathrm{sec})$ component was resolved adequately. Figure $3 B$ shows a representative shut-time distribution for AMPA fitted to the sum of four components. The mean time constants for the shut-time distributions (excluding the fastest component of five-component fits) were $0.30 \pm 0.04,4.0 \pm$ $1.8,53 \pm 17$, and $254 \pm 67 \mathrm{msec}(n=7)$.

The burst-lengths of AMPA receptors, rather than the apparent open-times, are more relevant to synaptic transmission, because this is likely to represent the duration of a channel event resulting from a single activation of a receptor (Colquhoun and Sigworth, 1995). Native AMPA receptors in cerebellar granule cells exhibit brief bursts, with relatively few openings per burst (resulting in burst lengths only slightly longer than the duration of individual openings; Wyllie et al., 1993). We found that recombinant
GluR4(i) receptors demonstrated brief bursts of openings. Bursts were defined by calculating a critical gap-length $\left(t_{\text {crit }}\right)$ from the shut-time distributions (see Materials and Methods). Figure $3 C$ illustrates a representative burst-length distribution for AMPAactivated events. These were fitted with two exponential components, yielding mean time constants of $0.19 \pm 0.02(58.6 \%)$ and $1.6 \pm 0.2 \mathrm{msec}(41.4 \%)(n=7)$.

For the GluR4(i) receptor, the kinetic properties of glutamate-activated channel openings were similar to those activated by AMPA. Figure $3 D$ shows an open-time distribution of glutamate-activated events; the mean open-time was $0.18 \pm 0.02 \mathrm{msec}(n=7)$. Shut-time distributions for glutamate (usually fitted with four exponential components; Fig. $3 E$ ) gave mean time constants of $0.31 \pm 0.03,2.3 \pm 0.5,36.8 \pm 12.1$, and $189.5 \pm 58.8 \mathrm{msec}$. Glutamate gave burst-length time constants (Fig. $3 F)$ of $0.12 \pm 0.01(69.7 \%)$ and $2.9 \pm 0.3 \mathrm{msec}(30.3 \%)$ $(n=7)$. A comparison of the burst-length distributions for AMPA and glutamate revealed that the fast component of the burst-length distribution was significantly slower for AMPA- 

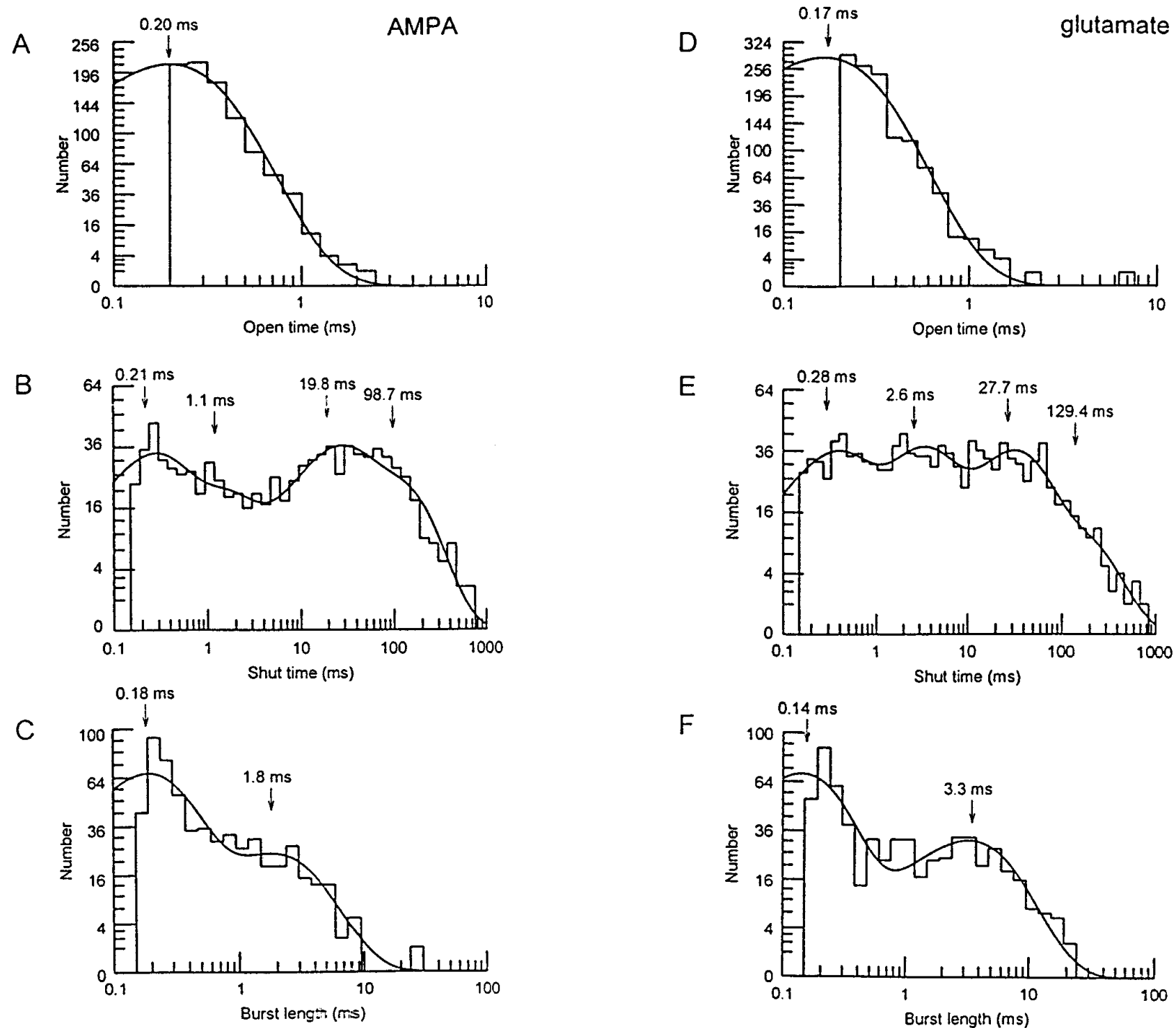

Figure 3. Kinetics of GluR4(i) channel events when activated by AMPA and glutamate. $A$, Open-time histogram for AMPA-activated events (5 $\mu$ M). The distribution was fitted to a single exponential with a time constant of $0.20 \mathrm{msec}$. $B$, Shut-time histogram from the same patch as shown in $A$. The distribution is fitted with four exponentials with time constants as shown. $C$, Burst-length histogram for AMPA-activated events from the same patch as $A$. The distribution is fitted to two exponential components. The burst-length time constants were 0.18 and 1.8 msec. $D$, Open-time histogram for glutamate-activated events $(100 \mu \mathrm{M})$. The distribution was fitted to a single exponential with a time constant of $0.17 \mathrm{msec}$. $E$, Shut-time histogram from the same patch as shown in $A$. The distribution is fitted with four exponentials with time constants as shown. $F$, Burst-length histogram for glutamate-activated events from the same patch as $A$. The distribution is fitted with two exponential components. The burst-length time constants were 0.14 and $3.3 \mathrm{msec}$.

activated events $(p<0.05)$, whereas the slow component was significantly slower for glutamate-activated events $(p<0.05)$. The means of the fitted burst-lengths were also similar: $0.7 \pm$ $0.1 \mathrm{msec}$ (AMPA) and $1.0 \pm 0.1 \mathrm{msec}$ (glutamate). Both agonists activated approximately two individual openings per burst $(1.97 \pm 0.05$ for AMPA and $2.32 \pm 0.23$ for glutamate); this is slightly higher than the number of openings per burst (1.2) seen for the high-conductance channels in cerebellar granule cells (Wyllie et al., 1993).

Homomeric edited GluR2(i) and GluR2(o) channels have a femtosiemens conductance

We have found previously that kainate receptors containing edited subunits have unusually low single-channel conduc- tances (Swanson et al., 1996). To investigate whether the editing state of the $\mathrm{Q} / \mathrm{R}$ site may also influence the single-channel conductance of AMPA receptors, we initially examined homomeric GluR2(i) and GluR2(o) receptors composed entirely of edited subunits.

Small whole-cell currents were detectable during application of agonists (with CZD; 30-100 $\mu \mathrm{M}$ ) to GluR2(i) receptors (Fig. 4A). No currents were detectable in outside-out patches from these cells. Thus estimates of channel conductance were obtained from variance analysis of the whole-cell responses. As shown in Figure $4 B$, this revealed a low single-channel conductance for GluR2(i) receptors (in the presence of CZD): $\gamma($ glutamate $)=211 \pm 59 \mathrm{fS}$ $(n=6), \gamma($ kainate $)=454 \pm 187 \mathrm{fS}(n=3)$, and $\gamma($ AMPA $)=$ 
A

GluR2(i)

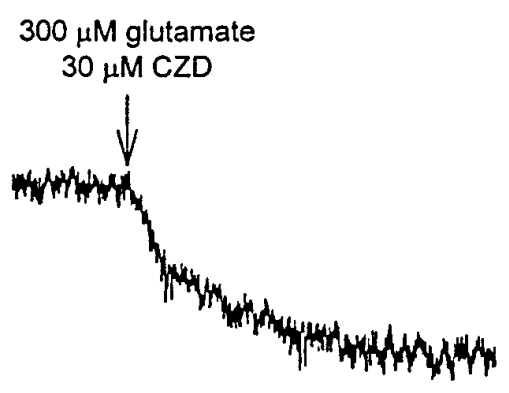

$\frac{10 \mathrm{pA}}{2 \mathrm{~s}}$

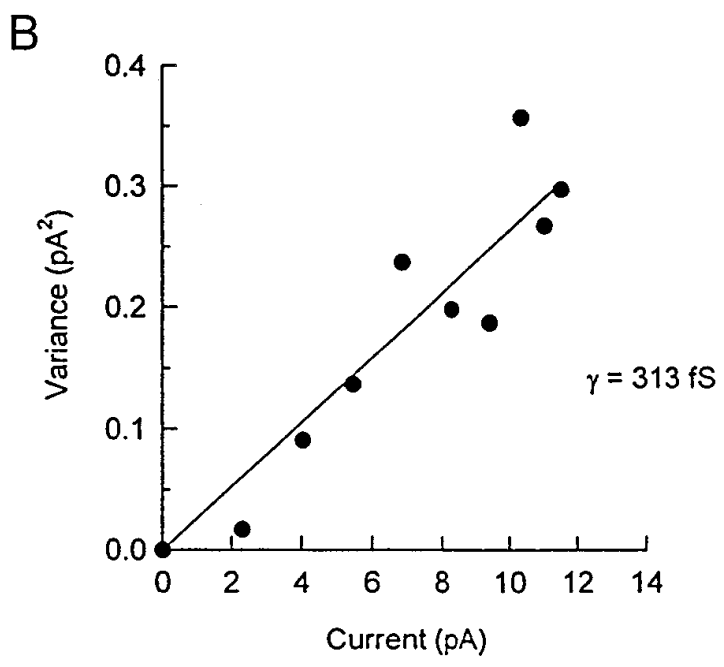

Figure 4. Homomeric GluR2(i) channels have a very low conductance. $A$, Whole-cell response activated by $300 \mu \mathrm{M}$ glutamate in the presence of $30 \mu \mathrm{M}$ CZD from a cell expressing GluR2(i) (arrow indicates application). $B$, A current-variance plot (fitted with a linear regression) for a whole-cell response from a cell expressing GluR2(i). The slope gave a mean conductance of $313 \mathrm{fS}$ for this cell. The holding potential was $-80 \mathrm{mV}$.

$356 \pm 125 \mathrm{fS}(n=3)$. These conductances were not significantly different. Because small variations in the measured DC current contributed disproportionately to the current variance (the channel-evoked noise increase was exceptionally small), these conductance values may be overestimates.

Homomeric GluR2(o) receptors were much less responsive than GluR2(i) receptors, and isolated cells rarely gave detectable whole-cell responses to bath application of agonists. In large clusters of electrically coupled cells, currents could be detected on application of AMPA or glutamate (when applied in the presence of $\mathrm{CZD} ; 100 \mu \mathrm{M})$, indicating that this subunit formed functional channels. In three isolated cells in which glutamate activated a detectable current, however, the noise increase during agonist application was negligible, indicating that the conductance of this channel was smaller than that estimated for GluR2(i), i.e., <300 fS.

To address the idea that RNA editing could alter single-channel conductance of AMPA receptors, we attempted to express the unedited form of GluR2(o), GluR2Q(o); however, this subunit failed to give detectable patch currents when expressed as a homomer and was therefore expressed heteromerically [with
GluR4(i)] to form a channel that contained only unedited subunits (see below).

\section{Heteromeric channels}

The majority of AMPA receptors involved in synaptic transmission are likely to be heteromeric assemblies that contain an edited GluR2 subunit (Jonas and Burnashev, 1995). To determine whether channel properties may be influenced by the splice isoform of GluR2, we coexpressed GluR2(i) or GluR2(o) with GluR4(i) subunits, and GluR2(i) with GluR4(o) subunits. We also compared the single-channel properties of two types of GluR2(o)/4(i) heteromeric receptors that differed in the $Q / R$ site editing of the GluR2(o) subunit. This allowed us to investigate further the idea that editing influences heteromeric AMPA receptor single-channel conductance. Certain other GluR2 and GluR4 permutations could not be investigated in detail because of poor responsiveness or nearly complete desensitization (see Table 1).

\section{Heteromeric GluR2/4 assemblies have intermediate channel conductances}

GluR2(i)/4(i) receptors gave discrete channel openings that were smaller in amplitude than those gated by homomeric GluR4(i) receptors. Furthermore, for this combination, glutamate-activated single-channel events were considerably briefer than those gated by AMPA (Fig. $5 A$ ) and could not be used to generate amplitude histograms ( $>90 \%$ of fitted glutamate-activated events were $<332$ $\mu \mathrm{sec}$ in duration). Time-course fitting of the AMPA-activated events gave amplitude histograms (Fig. $5 B$ ) that were best-fitted with two Gaussian components with conductance levels of $4.0 \pm$ $0.2(91.8 \%)$ and $8.1 \pm 0.4 \mathrm{pS}(8.2 \%)(n=8)$. These conductances were markedly lower than those gated by AMPA at the GluR4(i) channel, allowing the two receptor species to be distinguished on the basis of their single-channel conductance. In some experiments, the incorporation of an edited GluR2 subunit into the receptor complex was verified by the linearity of the currentvoltage relationship in the presence of $100 \mu \mathrm{M}$ spermine in the pipette solution (Kamboj et al., 1995).

GluR2(o)/4(i) channels gave small discrete conductance levels in response to glutamate and AMPA (Fig. 5C). The AMPAactivated events were similar in amplitude to those gated by GluR2(i)/4(i) receptors, suggesting that the GluR2 splice isoform was not influencing channel conductance when coassembled with GluR4(i). AMPA-activated events (Fig. 5D) gave amplitude histograms that were again best-fitted with the sum of two Gaussian curves with conductance levels of $4.3 \pm 0.2(85.0 \%)$ and $9.4 \pm 0.6$ pS $(15.0 \%)(n=4)$. The single-channel currents activated by glutamate were noticeably longer for GluR2(o)/4(i) than for GluR2(i)/4(i) channels, and in two patches yielded sufficient data from time-course fitting to generate amplitude histograms. Glutamate-activated events had similar conductance levels (4.0 and $9.6 \mathrm{pS}$ ).

We analyzed the kinetics of the heteromeric channels by constructing open-time histograms of the GluR2(i)/4(i) and GluR2(o)/4(i) channel events (Fig. 6A,B). The low conductance and brief dwell-times of the individual events prevented a rigorous kinetic analysis of these channels, and we have therefore limited our description to apparent open-times of AMPA-activated events. The open-time distributions for AMPA-evoked GluR2(i)/ 4(i) channel events were best-fitted with the sum of two exponential components (Fig. $6 A$ ) with mean time constants of $0.58 \pm 0.10$ $(78.5 \%)$ and $1.5 \pm 0.2 \mathrm{msec}(21.5 \%)(n=8)$. As shown in Figure 

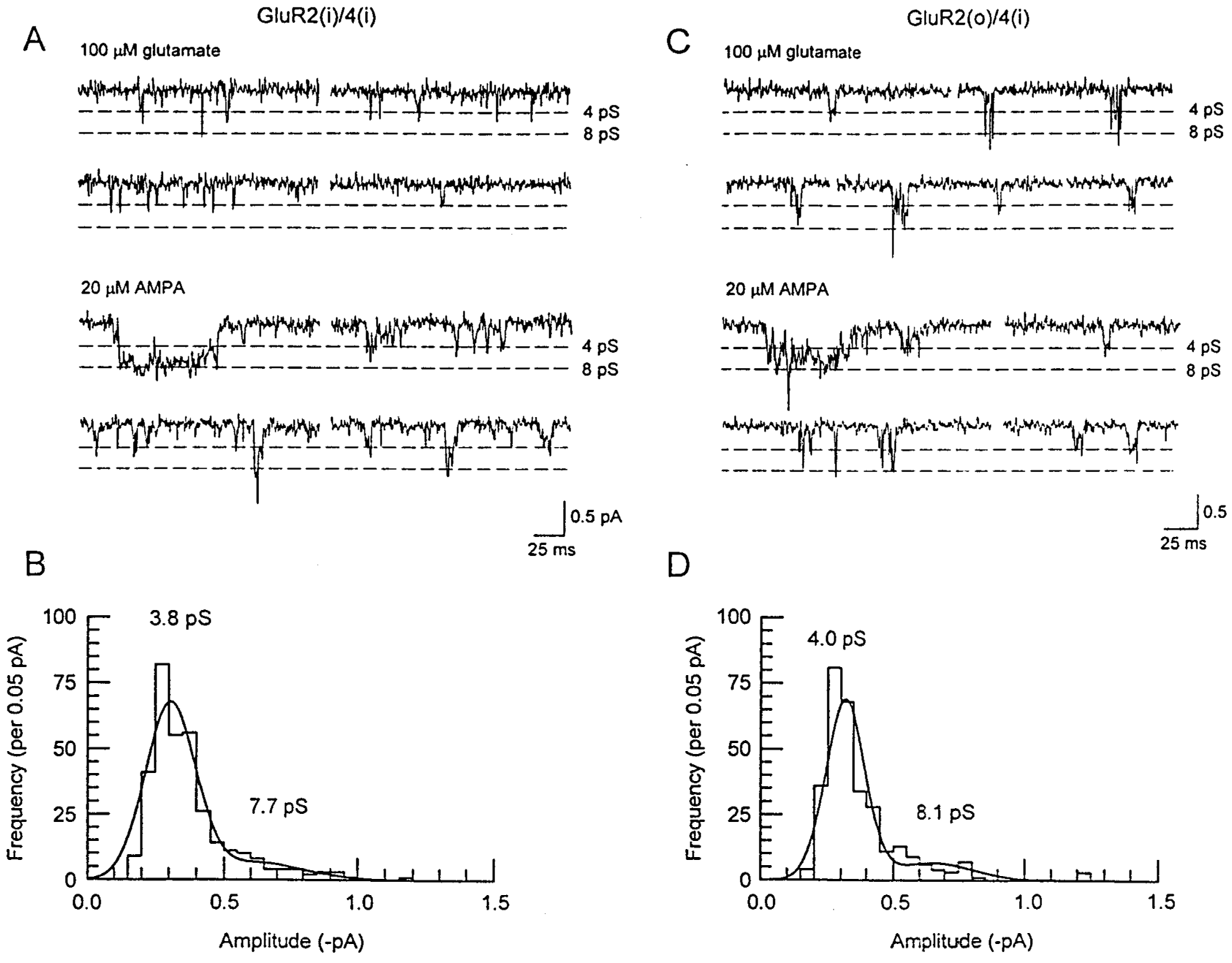

Figure 5. GluR2(i)/4(i) and GluR2(o)/4(i) channels and amplitude histograms. $A$, GluR2(i)/4(i) single-channel events activated by $100 \mu \mathrm{M}$ glutamate (top two traces) and $20 \mu \mathrm{M}$ AMPA (bottom two traces) in an outside-out patch. Channel openings in response to glutamate were very fast and poorly resolved and did not yield sufficient data to construct amplitude histograms. In contrast, time-course fitting revealed two AMPA-activated conductance levels of $\sim 4$ and $\sim 8 \mathrm{pS}$, which are marked by dashed lines. The calibration is $0.5 \mathrm{pA}$ and $25 \mathrm{msec} . B$, An amplitude histogram for AMPA-activated events fitted to two Gaussian components. The AMPA-activated conductances for this patch were 3.8 and $7.7 \mathrm{pS}$. $C$, GluR2(o)/4(i) single-channel events activated by $100 \mu \mathrm{M}$ glutamate (top two traces) and $20 \mu \mathrm{M}$ AMPA (bottom two traces) in an outside-out patch. Time-course fitting revealed two conductance levels of $\sim 4$ and $\sim 8 \mathrm{pS}$. $D$, An amplitude histogram for AMPA-activated events fitted to two Gaussian components with means of 4.0 and $8.1 \mathrm{pS}$. The holding potential was $-80 \mathrm{mV}$.

$6 B$, GluR2(o)/4(i) open-time distributions gave similar mean time constants of $0.42 \pm 0.10(89.5 \%)$ and $1.1 \pm 0.1 \mathrm{msec}(10.5 \%)(n=$ 4) for AMPA openings. GluR2(o)/4(i) events evoked by glutamate and AMPA did not differ markedly in their dwell-times (data not shown). Because of the low resolution, these values are likely to approximate the burst-lengths of the channels.

The GluR2(i)/4(o) heteromeric assembly was also examined. This combination was much less sensitive to agonist application when examined in the outside-out patch-clamp configuration than the combinations described above. No discrete channel openings were observed. Noise analysis of glutamate-evoked inward currents $(\sim 0.5 \mathrm{pA} ; 100 \mu \mathrm{M}$ glutamate in the presence of $100 \mu \mathrm{M}$ $\mathrm{CZD} ; n=2$ ) gave a conductance estimate of $1.0 \mathrm{pS}$ (Table 1). Whole-cell noise analysis of glutamate evoked currents gave a similar estimate of $1.6 \pm 0.3 \mathrm{pS}(n=3)$.

It has been suggested that AMPA receptors consisting of heteromeric subunit assemblies contain different numbers of
GluR2 subunits, but that the incorporation of a single GluR2 subunit is sufficient to confer calcium impermeability (Geiger et al., 1995; Jonas and Burnashev, 1995). There is supporting evidence for a mixed receptor population from experiments that have examined the effects of CZD on receptor desensitization in hippocampal neurons (Fleck et al., 1996). If the number of copies of GluR2 can vary, this raises the question of whether a single GluR2 subunit is sufficient to reduce the conductance of GluR2/GluR4 receptors. In the current experiments, we did not observe heterogeneity in the single-channel conductances; such heterogeneity might be expected if conductance varied markedly with the number of copies of GluR2. On coexpression of two subunits at $1: 1$ ratio, $81 \%$ of the resulting channels might be expected to contain two or more GluR2 subunits, $3 \%$ to contain no GluR2, and $16 \%$ to include one GluR2 (assuming binomial distribution) (Geiger et al., 1995; Jonas and Burnashev, 1995). 

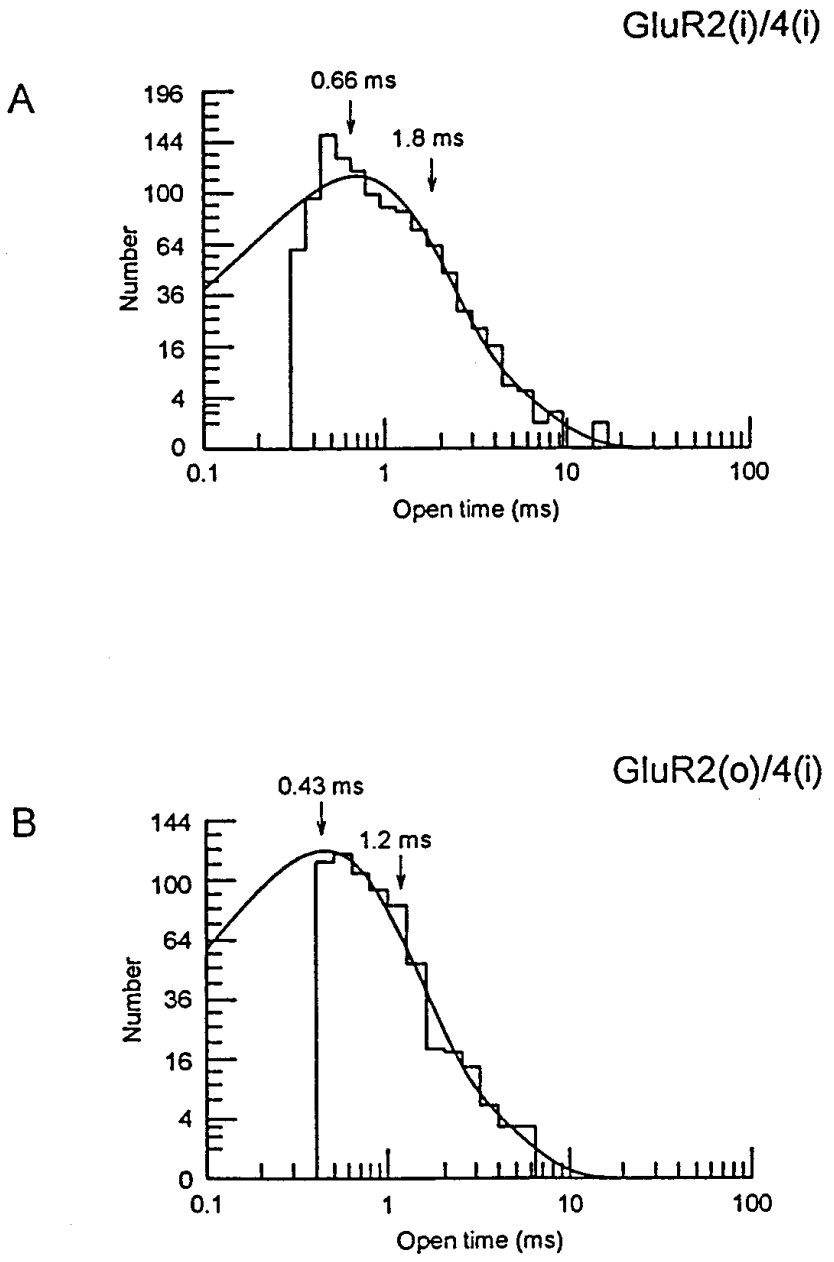

Figure 6. Open-time distributions of GluR2(i)/4(i) and GluR2(o)/4(i) channel events. $A$, Open-time distributions for AMPA-activated events in a patch from a cell expressing GluR2(i)/GluR4(i) receptors. In this record the resolution was set to $0.3 \mathrm{msec}$. The distribution was fitted with two exponential components with time constants of 0.7 and 1.8 msec. $B$, Open-time distribution for AMPA-activated events in a patch containing GluR2(o)/4(i) receptors. In this record the resolution was set to 0.4 msec. The distribution was fitted with two exponential components with time constants of 0.4 and $1.2 \mathrm{msec}$.

To allow us to look selectively at heteromeric assemblies likely to contain a single copy of GluR2, we recorded AMPAevoked single-channel events in the presence of $1.5 \mu \mathrm{M}$ Joro spider toxin (JSTX-3). This selective blocker of calciumpermeable receptors (Blaschke et al., 1993) would be expected to block channels arising from homomeric GluR4 receptors but not those arising from receptors incorporating one or more copies of GluR2. We recorded from cells transfected with a 1:10 ratio of GluR2(i)/GluR4(i). If the levels of subunit protein relate directly to the relative amounts of cDNA used, and channel assemblies incorporate subunits binomially, then this ratio would give $31 \%$ of channels with one copy of the GluR2 subunit (assuming a pentamer); most other channels will be GluR4 homomers and hence will be blocked by JSTX-3. Under these conditions, two patches (exposed to $30 \mu \mathrm{M}$ AMPA) that gave high conductance events in the absence of JSTX-3 gave openings of 5 and $9 \mathrm{pS}$ in its presence. These were indistinguishable from our other recordings (described above) obtained from cells transfected with a 1:1 ratio of GluR2/GluR4 subunits. In two other patches, mean channel conductances were similar to those seen with homomeric GluR4, and openings were reduced significantly in frequency by JSTX-3. In the latter case, we assume that there was no incorporation of GluR2 into the receptors contained within the patch. Overall, these preliminary results are consistent with the idea that incorporation of a single copy of GluR2, within a GluR2/4 assembly, results in low conductance channels ( $\sim 5$ and $\sim 9 \mathrm{pS})$.

\section{Properties of heteromeric GluR2(o)/4(i) channels containing unedited GluR2}

We have examined GluR2(o)/4(i) channels containing GluR2Q(o), an unedited form of GluR2, to allow a direct comparison with the heteromeric combination containing edited GluR2(o). As shown in Figure 7A, outside-out patches containing calcium-permeable GluR2Q(o)/4(i) receptors exhibited well resolved single-channel events in response to glutamate and AMPA. GluR2Q(o)/4(i) receptors gave a range of channel amplitudes. Figure $7 B$ shows an example of an amplitude distribution from AMPA-activated events. Distributions from four patches were best-fitted with the sum of three Gaussian components with mean conductance levels of $7.4 \pm 0.5$, $15.4 \pm 1.0$, and $24.4 \pm 1.5 \mathrm{pS}$ (relative areas $58 \pm 4,30 \pm 2$, and $11 \pm 2 \%$, respectively; $n=4$ ). One patch also had a fourth component of $35 \mathrm{pS}$. Glutamate primarily activated conductance levels of $7.9 \pm 0.3$ and $16.5 \pm 0.5 \mathrm{pS}$ (relative areas 67 and $27 \% ; n=4)$; however, in two of four patches, higher conductance levels of 24.4 and $28.5 \mathrm{pS}$ (11 and $10 \%$ of fitted openings, respectively) were also observed. The difference between the channel conductances gated by homomeric GluR4(i) and heteromeric GluR2Q(o)/4(i) is apparent from a comparison of Figures $7 B$ and $2 B$. Although both channels are expected to be calcium-permeable (Burnashev et al., 1992), GluR2Q(o)/ 4(i) gave a greater proportion of high conductance levels (with both agonists). Thus, although GluR4(i) and GluR2Q(o)/4(i) channels may open to similar conductance states, the "preferred" conductance levels seem to be different. Therefore the GluR2Q(o)/4(i) channel seems to have a unique conductance "signature," distinguishing it from the GluR4(i) channel, which is similarly composed entirely of unedited subunits.

The kinetics of the GluR2(Q)/4(i) channels were similar to those of homomeric GluR4(i) channels. Open-time distributions of AMPA-activated events (Fig. $8 \mathrm{~A}$ ) were generally bestfitted with a single exponential component with a mean of $0.25 \pm 0.03 \mathrm{msec}(n=4)$. Shut-time distributions (Fig. $8 B)$ were fitted with four or five exponential components with mean time constants of $0.15 \pm 0.02,0.68 \pm 0.12,22.4 \pm 3.5$, and $139.9 \pm 28.6 \mathrm{msec}(n=4)$. Figure $8 C$ shows a typical example of the distributions of burst-lengths for GluR2Q(o)/4(i) channel events; mean time constants for the two exponential fits were $0.30 \pm 0.10(56.9 \%)$ and $1.89 \pm 0.44 \mathrm{msec}(43.1 \%)$. The channel kinetics were similar when activated by glutamate or AMPA (data not shown). A comparison of these data with those of GluR4(i) suggests that the kinetics of channel activations are quite similar for homomeric and heteromeric calciumpermeable channels, despite the fact that they adopt different preferred conductance states.

\section{DISCUSSION}

The identity of the subunits involved in forming native AMPA receptors may have important implications for synaptic transmission at a particular synapse. During cerebellar granule cell 


\section{GluR2Q(o)/4(i)}

A

$30 \mu \mathrm{M}$ glutamate

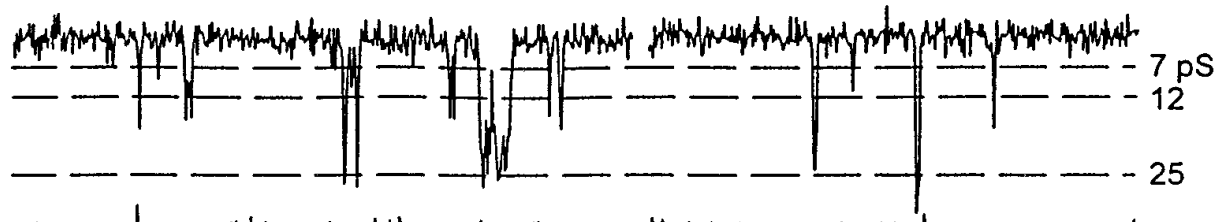

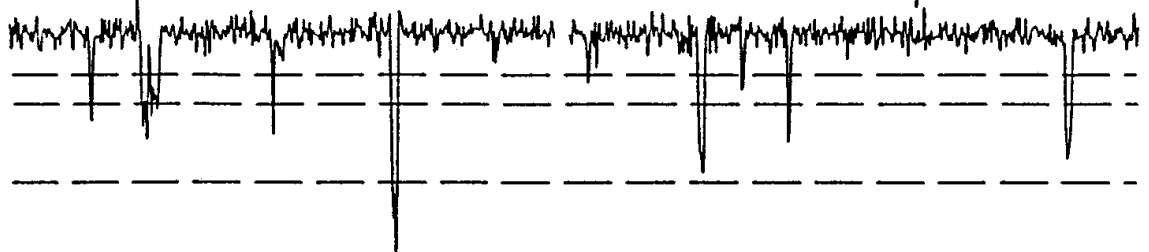

$3 \mu \mathrm{M}$ AMPA
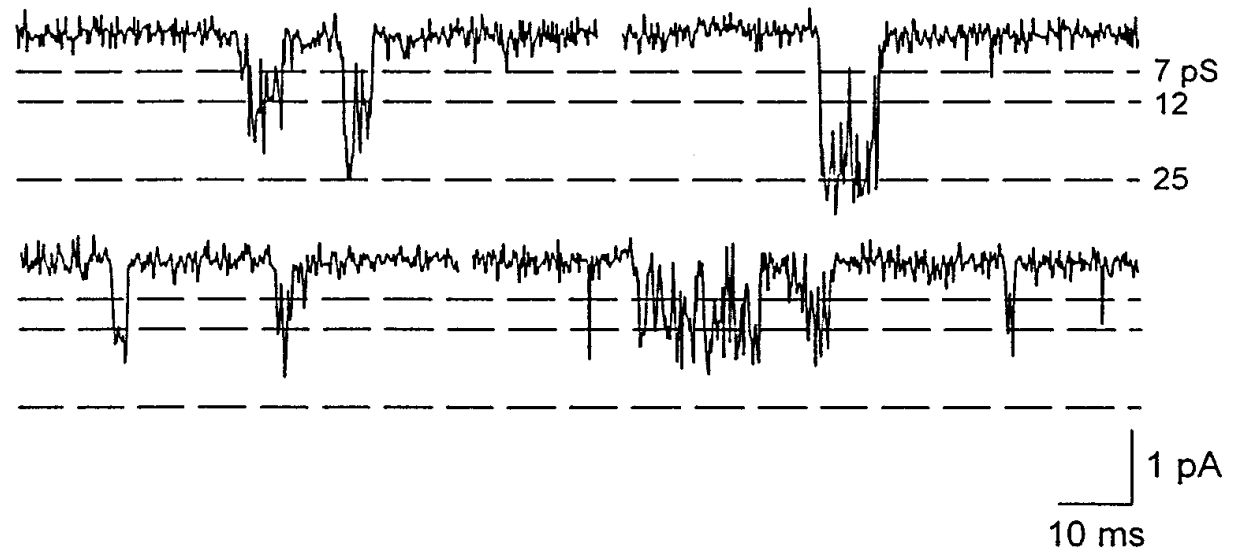

B

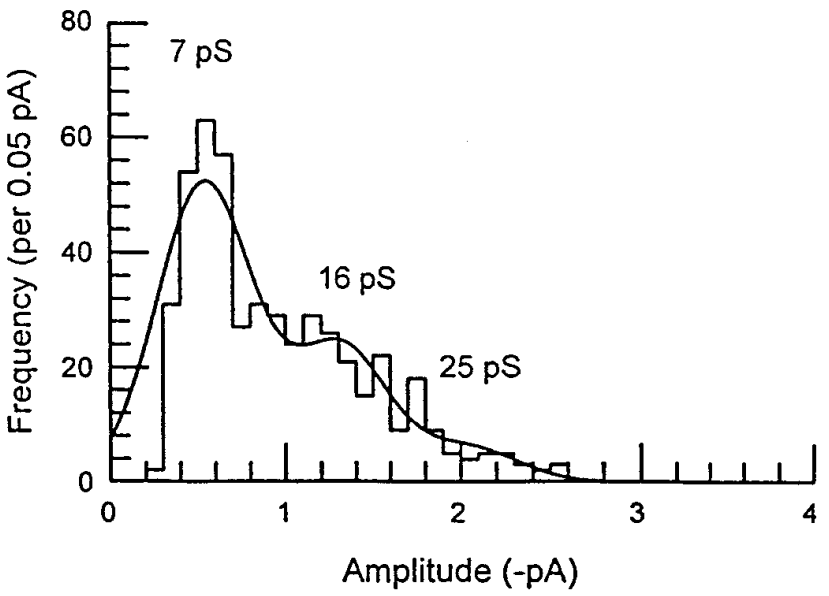

Figure 7. GluR2Q(o)/4(i) single channels and amplitude histogram. $A$, GluR2Q(o)/4(i) single-channel events activated by $30 \mu \mathrm{M}$ glutamate (top two traces) and $20 \mu \mathrm{M}$ AMPA (bottom two traces) in an outside-out patch. Timecourse fitting of channel openings gave conductance levels of 7, 12, and 25, which are marked by dashed lines. The calibration is $1.0 \mathrm{pA}$ and $10 \mathrm{msec}$. $B$, An amplitude histogram for AMPA-activated events from a different patch than that in $A$ fitted to three Gaussian components. The holding potential was $-80 \mathrm{mV}$.

development, there is evidence for the presence of mRNA for both flip and flop isoforms of GluR2 and GluR4 subunits, with flop isoform expression increasing with age (Monyer et al., 1991; Mosbacher et al., 1994). The desensitization kinetics of receptors formed from these subunits have been well characterized (Mosbacher et al., 1994), and properties of several distinct granule cell AMPA receptors have been described (Cull-Candy et al., 1988; Wyllie et al., 1993). Our experiments therefore aimed to build on this information by examining combinations of GluR2 and GluR4 subunits and to compare these with the AMPA receptors identified in cerebellar granule cells. Furthermore, in view of the profound effect of RNA editing on kainate receptor channel conductance (Swanson et al., 1996), and the fact that the GluR2 subunit is normally edited in vivo, we were interested in the possibility that properties of AMPA receptor assemblies may be similarly modified by inclusion of edited subunits.

\section{Influence of RNA editing on AMPA receptor single-channel conductance}

$\mathrm{Q} / \mathrm{R}$ site editing of non-NMDA glutamate receptor subunits is known to diminish both $\mathrm{Ca}^{2+}$ permeability of the channel (Hume et al., 1991; Burnashev et al., 1992) and its block by intracellular polyamines (Bowie and Mayer, 1995; Kamboj et al., 1995; Koh et 

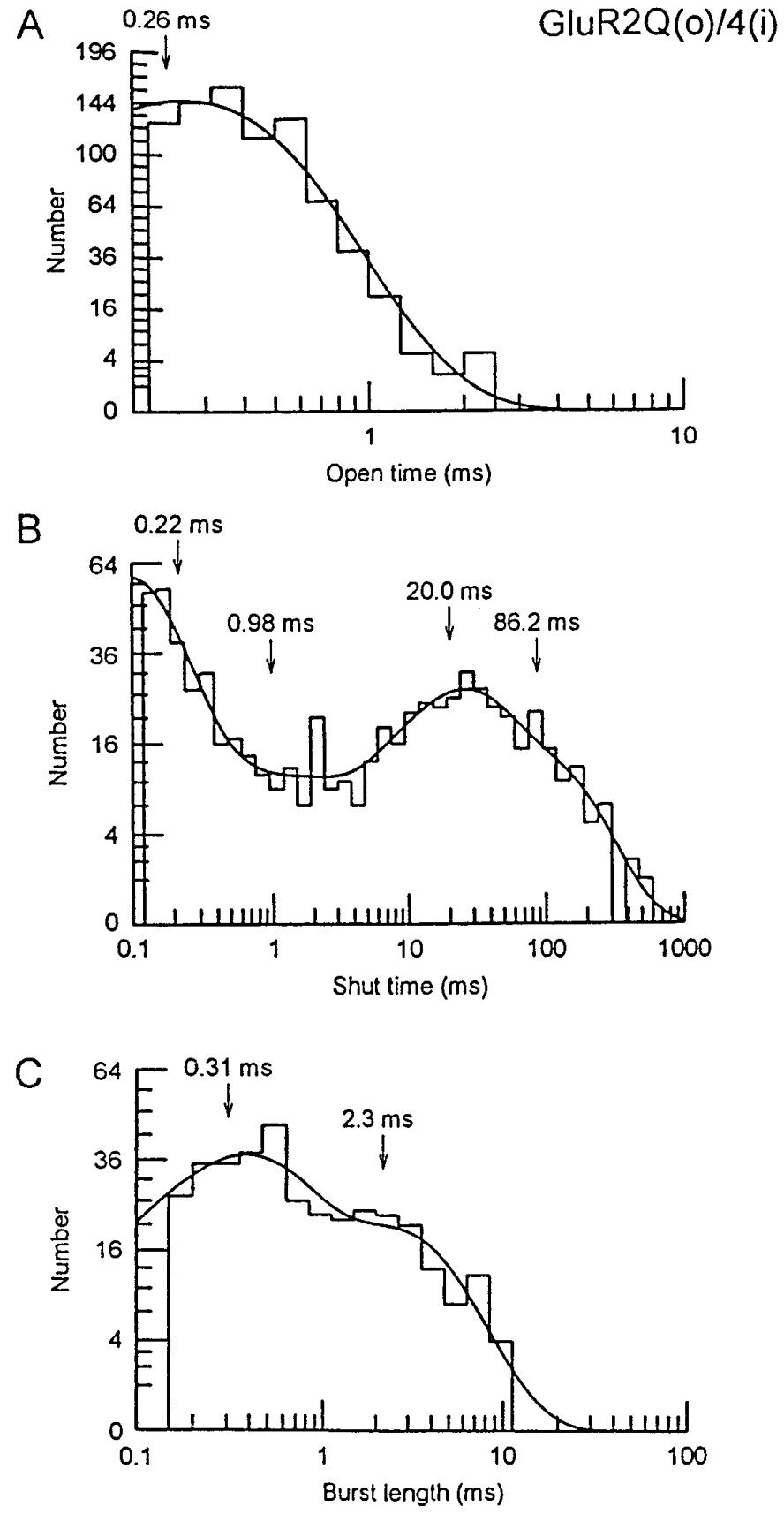

Figure 8. Kinetics of GluR2Q(o)/4(i) channel events when activated by AMPA. $A$, Open-time histogram for AMPA-activated events $(5 \mu \mathrm{M})$. The distribution was fitted to a single exponential with a time constant of 0.26 msec. $B$, Shut-time histogram from the same patch as shown in $A$. The distribution is fitted with the sum of four exponentials with time constants as shown. $C$, Burst-length histogram for AMPA-activated events from the same patch as $A$. The distribution is fitted with two exponential components. The burst-length time constants were 0.31 and $2.3 \mathrm{msec}$. These distributions were compiled from time-course fitted events.

al., 1995). In addition, editing at this site reduces the singlechannel conductance of kainate receptors (Swanson et al., 1996). The present experiments suggest that AMPA receptors composed of or containing an edited subunit also have a low conductance compared with their unedited counterparts. Thus, the singlechannel conductance was highest for the $\mathrm{Ca}^{2+}$-permeable channels [GluR4(i) and GluR2Q(o)/4(i)], lowest for the $\mathrm{Ca}^{2+}$. impermeable channels formed entirely of edited subunits [GluR2(i) and GluR2(o)], and intermediate for the $\mathrm{Ca}^{2+}$ impermeable heteromeric channels composed of both edited and unedited subunits [GluR2(i)/4(i), GluR2(o)/4(i), and GluR2(i)/ 4(o)]. Our preliminary experiments with JSTX-3 suggest that the presence of a single GluR2 subunit may be sufficient to produce a marked drop in channel conductance. Our experiments, however, do not allow us to say whether channel conductance may vary with the number of copies of GluR2 incorporated into heteromeric assemblies (assuming that the number of GluR2 subunits varies; Jonas and Burnashev, 1995). The apparent lack of heterogeneity in channel conductance with 1:1 plasmid ratio could mean either that channel conductance is not changed further by incorporation of additional copies of GluR2 or that all channels with more than one copy of GluR2 have a femtosiemens conductance and are therefore not visible as discrete events.

As reported previously, the small size of GluR2 currents precluded direct comparisons of homomeric edited and unedited GluR2 receptors in outside-out patches (Mosbacher et al., 1994). Instead, we have compared heteromeric assemblies containing unedited and edited versions of GluR2, i.e., GluR2Q(o)/4i versus GluR2R(o)/4(i). For these combinations, there was a clear reduction in weighted mean conductance (approximately threefold) and in resolved single-channel conductance levels $(6,12$, and $22 \mathrm{pS}$ vs 4 and 9 pS; Table 1) when the receptors contained edited GluR2 subunits.

Moreover, the unusually low conductances observed for homomeric GluR2(i) and 2(o) receptors were reminiscent of those described for kainate receptors composed of edited subunits: GluR6(R) ( $250 \mathrm{fS}$ ) or GluR5(R) (<200 fS) (for details, see Swanson et al., 1996). Thus homomeric non-NMDA receptors composed solely of edited subunits seem to be characterized by channel conductances in the femtosiemens range.

Our present data, when considered together with previous studies on neuronal channels, imply that native $\mathrm{Ca}^{2+}$. permeable non-NMDA receptors may exhibit higher singlechannel conductances than $\mathrm{Ca}^{2+}$-impermeable forms. For example, AMPA receptors in hippocampal interneurons have a relatively high $\mathrm{Ca}^{2+}$-permeability $\left(P_{\mathrm{Ca} / \mathrm{Cs}} \sim 1.8\right)$ and singlechannel conductance (23 pS; Koh et al., 1995) compared with those in primary neurons $\left(P_{\mathrm{Ca} / \mathrm{Cs}} \sim 0.05 ; 10 \mathrm{pS}\right.$; Spruston et al., 1995). Similarly, the high single-channel conductance of AMPA receptors from neocortical interneurons $(\sim 30 \mathrm{pS})$, compared with pyramidal cells $(\sim 10 \mathrm{pS}$; Hestrin, 1993), seems to be related to the low expression level of GluR2 mRNA in pyramidal cells versus interneurons (Lambolez et al., 1996). On the basis of recent molecular data, it has been proposed that the level of GluR2 expression may determine the calcium permeability of AMPA receptors in a given cell (Geiger et al., 1995; Jonas and Burnashev, 1995). Our results suggest that GluR2 subunit incorporation may also be important in determining the single-channel conductance of AMPA receptors.

\section{Agonist-dependence of GluR4(i) conductance}

There are several possible explanations for the observation that kainate gave a lower conductance estimate than AMPA at the GluR4(i) receptor both in whole-cell recordings and in isolated patches (where the channels could be resolved directly). First, kainate may preferentially activate lower conductance states than those opened by AMPA or glutamate; a similar suggestion has been made to account for the action of different agonists at certain $\mathrm{GABA}_{\mathrm{A}}$ receptors (Mistry and Hablitz, 1990). Second, 
signal filtering of noise variance may reduce the estimated conductance of channels opened by kainate. Although the time constants obtained from spectral analysis of kainate noise and AMPA noise were similar, kainate spectra contained a larger proportion of the fast kinetic component. It is therefore possible that kainate activates events of brief duration that were attenuated by the recording system. Other explanations, such as low-affinity open-channel block by kainate resulting in fewer resolvable openings (Ogden and Colquhoun, 1985), seem unlikely given the lack of concentration dependence of the conductance estimate. Similarly, it seems unlikely that the agonist dependence of conductance can be ascribed to a heterogeneous population of GluR4(i) receptors, although we cannot rule out the possibility that distinct GluR4(i) receptor isoforms might arise from different post-translational modifications of individual receptors or variable numbers of subunits per receptor complex. Independent evidence for a different open state for kainate versus AMPA or glutamate-activated AMPA receptors is provided by the observation that kainate acts as a "partial agonist" at AMPA receptors after suppression of desensitization by CZD (Partin et al., 1993).

The apparent agonist dependence of conductance of GluR4(i) channels [and of GluR2(i)/4(i) channels] reported here seems similar to the behavior of "low-conductance" channels from cerebellar granule cells (Wyllie et al., 1993). In these native channels, kainate induced a noise increase and gave an estimated singlechannel conductance of $\sim 1 \mathrm{pS}$, whereas AMPA activated discrete channel events with conductances of $\sim 5$ and $10 \mathrm{pS}$. In this previous study, however, it was unclear whether the different conductances activated by AMPA and kainate arose from distinct channel species or whether the two agonists produced different conductances from the same receptor. The results presented here clearly favor the latter possibility.

\section{Comparison with native AMPA receptors}

The present experiments have focused on the properties of AMPA subunits whose mRNAs are present in cerebellar granule cells (Monyer et al., 1991; Mosbacher et al., 1994). Cultured granule cells have at least three distinct AMPA receptor channels that can be distinguished on the basis of their single-channel properties: "high-conductance" ( 10, 20, and $30 \mathrm{pS})$, "lowconductance" ( $\sim 5$ and $10 \mathrm{pS})$, and "femtosiemens" channels (Cull-Candy et al., 1988; Wyllie et al., 1993).

A comparison of our present results with those obtained from channels in granule cells has revealed some marked similarities. For example, the high-conductance channels in cerebellar granule cells resemble the GluR4(i) channel in the amplitude of their openings, the number of resolvable conductance levels (three), and the relative proportions of these levels. Furthermore, the native high-conductance channel resembles the GluR4(i) channel in being sensitive to block by intracellular polyamines and therefore $\mathrm{Ca}^{2+}$-permeable (S. Kamboj and S. Cull-Candy, unpublished observations). Thus the native high-conductance channel is unlikely to be a heteromeric assembly incorporating the GluR2 subunit. Unlike GluR4(i) receptors, however, the native channel gives similar conductance levels with kainate and AMPA (Wyllie et al., 1993). Although we examined other combinations of GluR2 and GluR4 subunits, we have not identified a recombinant receptor that exhibits all of the single-channel properties of the high-conductance channel present in cerebellar granule cells. It is possible that GluR4(i) receptors in transfected mammalian cells behave differently from those in neurons. Alternatively, the native high-conductance receptor channel may arise from subunit combinations that were not examined in detail because of low responsiveness or high degree of desensitization; these channels include GluR4(o), mixtures of flip/flop isoforms of GluR4, and receptors that included the GluR4c splice variant (Gallo et al., 1992), all of which may occur in granule cells in situ (Gallo et al., 1992; Mosbacher et al., 1994).

The heteromeric channel combinations GluR2(o)/4(i) and GluR2(i)/4(i) exhibit AMPA-activated conductance levels (4 and $8 \mathrm{pS}$ ), which resemble the 5 and $10 \mathrm{pS}$ levels of the native low-conductance channels in granule cells in both their amplitudes and relative proportions. Thus the GluR2(i or o)/4(i) combinations are potential candidates for the low-conductance channel found in granule cells. This is supported further by the fact that both the native and recombinant low-conductance channels are polyamine-insensitive (S. Kamboj and S. Cull-Candy, unpublished observations), indicative of the presence of GluR2 subunits in AMPA receptors (Kamboj et al., 1995).

Finally, our experiments suggest that we may have identified the femtosiemens channel described previously in cerebellar granule cells from young animals (Cull-Candy et al., 1988). The present results, together with our previous observations on kainate receptors, suggest that homomeric non-NMDA receptors composed of edited subunits have unusually low conductances ( 200-300 fS). Although mRNA for GluR6 (a kainate subunit subject to editing) and GluR2 (the AMPA subunit that is entirely edited in vivo) are both present in granule cells, there is currently little evidence for functional kainate receptors in these cells. It therefore seems likely that GluR2 subunits form the femtosiemens channels in cerebellar granule cells.

Under certain conditions, the expression of GluR2 subunits can be downregulated (Condorelli et al., 1993), which is accompanied by corresponding changes in channel properties (Kamboj et al., 1995). It is therefore tempting to speculate that changes in the level of expression of the GluR2 subunit could act as a mechanism for altering the gain of a synaptic response as well as for modifying $\mathrm{Ca}^{2+}$ permeability.

\section{REFERENCES}

Barker JL, Mathers DA (1981) GABA analogues activate channels of different duration on cultures mouse spinal neurons. Science 212:358-361.

Blaschke M, Keller BU, Rivosecchi R, Hollmann M, Heinemann S, Konnerth A (1993) A single amino acid determines the subunit-specific spider toxin block of $\alpha$-amino-3-hydroxy-5-methyl-isoxazole-4-propionate/kainate receptor channels. Proc Natl Acad Sci USA 90:6528-6532.

Bowie D, Mayer M (1995) Inward rectification of both AMPA and kainate subtype glutamate receptors generated by polyamine-mediated ion channel block. Neuron 15:453-462.

Burnashev N, Monyer H, Seeburg PH, Sakmann B (1992) Divalent ion permeability of AMPA receptor channels is dominated by the edited form of a single subunit. Neuron 8:189-198.

Chen C, Okayama H (1987) High-efficacy transformation of mammalian cells by plasmid DNA. Mol Cell Biol 7:2745-2752.

Colquhoun D, Sigworth FJ (1995) Fitting and statistical analysis of single-channel records. In: Single-channel recording (Sakmann B, Neher E, eds), pp 483-587. New York: Plenum.

Condorelli DF, Dell'Albani P, Aronica E, Genazzani AA, Casabona G, Corsaro M, Balázs R, Nicoletti F (1993) Growth conditions differentially regulate the expression of $\alpha$-amino-3-hydroxy-5-methyl-isoxazole4-propionate (AMPA) receptor subunits in cultured neurons. J Neurochem 61:2133-2139.

Cull-Candy SG, Miledi R, Parker I (1981) Single glutamate-activated channels recorded from locust muscle fibres with perfused patch-clamp electrodes. J Physiol (Lond) 321:195-210. 
Cull-Candy SG, Howe J, Ogden DC (1988) Noise and single channels activated by excitatory amino acids in rat cerebellar granule neurones. J Physiol (Lond) 400:189-222.

Fleck MW, Bähring R, Patneau DK, Mayer ML (1996) AMPA receptor heterogeneity in rat hippocampal neurons revealed by differential sensitivity to cyclothiazide. J Neurophysiol 75:2322-2333.

Gallo V, Upson LM, Hayes WP, Vyklicky L, Winters CA, Buonanno A (1992) Molecular cloning and developmental analysis of a new glutamate receptor subunit isoform in cerebellum. J Neurosci 12:1010-1023.

Gardner P, Ogden DC, Colquhoun D (1984) Conductances of singlechannels opened by nicotinic agonists are indistinguishable. Nature 309:160-162.

Geiger JRP, Melcher T, Koh D-S, Sakmann B, Seeburg PH, Jonas P, Monyer H (1995) Relative abundance of subunit mRNAs determines gating and $\mathrm{Ca}^{2+}$ permeability of AMPA receptors in principle neurons and interneurons in rat CNS. Neuron 15:193-204.

Hestrin S (1993) Different glutamate receptor channels mediate fast excitatory synaptic currents in inhibitory and excitatory cortical neurons. Neuron 11:1083-1091.

Hollmann M, Heinemann S (1994) Cloned glutamate receptors. Annu Rev Neurosci 17:31-108.

Hume RI, Dingledine R, Heinemann SF (1991) Identification of a site in glutamate receptor subunits that controls calcium permeability. Science 253:1028-1031.

Jonas P, Burnashev N (1995) Molecular mechanisms controlling calcium entry through AMPA-type glutamate receptor channels. Neuron 15:987-990.

Jonas P, Sakmann B (1992) Glutamate receptor channels in isolated patches from CA1 and CA3 pyramidal cells of rat hippocampal slices. J Physiol (Lond) 455:143-171.

Kamboj SK, Swanson GT, Cull-Candy SG (1995) Intracellular spermine confers rectification on rat calcium-permeable AMPA and kainate receptors. J Physiol (Lond) 486:297-303.

Koh D-S, Geiger JRP, Jonas P, Sakmann B (1995) $\mathrm{Ca}^{2+}$-permeable AMPA and NMDA receptor channels in basket cells of rat hippocampal dentate gyrus. J Physiol (Lond) 485:383-402.

Köhler M, Kornau HC, Seeburg PH (1994) The organization of the gene for the functionally dominant $\alpha$-amino-3-hydroxy-5-methylisoxazole-4-propionic acid receptor subunit GluR-B. J Biol Chem 269:17367-17370.

Lambolez B, Robert N, Perrais D, Rossier J, Hestrin S (1996) Correlation between kinetics and RNA splicing $\alpha$-amino-3-hydroxy-5-methylisoxazole-4-propionic acid receptors in neocortical neurons. Proc Natl Acad Sci USA 93:1797-1802.
Lomeli H, Mosbacher J, Melcher T, Höger T, Geiger JRP, Kuner T, Monyer H, Higuchi M, Bach A, Seeburg PH (1994) Control of kinetic properties of AMPA receptor channels by nuclear RNA editing. Science 266:1709-1713.

Mistry DK, Hablitz JJ (1990) Activation of subconductance states by gamma-aminobutyric acid and its analogs in chick cerebral neurons. Pflügers Arch 416:454-461.

Monyer H, Seeburg PH, Wisden W (1991) Glutamate-operated channels: developmentally early and mature forms arise by alternative splicing. Neuron 6:799-810.

Mosbacher J, Schoepfer R, Monyer H, Burnashev N, Seeburg PH, Ruppersburg JP (1994) A molecular determinant for submillisecond desensitization in glutamate receptors. Science 266:1059-1062.

Ogden DC, Colquhoun D (1985) Ion channel block by acetylcholine, carbachol and suberyldicholine at the frog neuromuscular junction. Proc R Soc Lond [Biol] 225:329-355.

Partin KM, Bowie D, Mayer ML (1995) Structural determinants of allosteric regulation in alternatively spliced AMPA receptors. Neuron 14:833-843.

Partin KM, Patneau DK, Winters CA, Mayer ML, Buonanno A (1993) Selective modulation of desensitization at AMPA versus kainate receptors by cyclothiazide and concanavalin A. Neuron 11: 1069-1082.

Seeburg PH (1993) The molecular biology of mammalian glutamate receptor channels. Trends Neurosci 16:359-364.

Seeburg PH (1996) The role of RNA editing in controlling glutamate receptor channel properties. J Neurochem 66:1-5.

Sommer B, Keinänen K, Verdoorn TA, Wisden W, Burnashev N, Herb A, Köhler M, Takagi T, Sakmann B, Seeburg PH (1990) Flip and flop: a cell-specific functional switch in glutamate-operated channels of the CNS. Science 249:1580-1585.

Sommer B, Köhler M, Sprengel R, Seeburg PH (1991) RNA editing in brain controls a determinant of ion flow in glutamate-gated channels. Cell 67:11-19.

Spruston N, Jonas P, Sakmann B (1995) Dendritic glutamate receptor channels in rat hippocampal CA3 and CA1 pyramidal neurons. J Physiol (Lond) 482:325-352.

Swanson GT, Feldmeyer D, Kaneda M, Cull-Candy SG (1996) Effect of RNA editing and subunit co-assembly on single-channel properties of recombinant kainate receptors. J Physiol (Lond) 492:129-142.

Wyllie DJ, Traynelis SF, Cull-Candy SG (1993) Evidence for more than one type of non-NMDA receptor in outside-out patches from cerebellar granule cells of the rat. J Physiol (Lond) 463:193-226. 